\title{
Digitalization of Russian Education: Changing Actors and Spaces of Governance
}

\author{
Nelli Piattoeva and Galina Gurova
}

\subsection{INTRODUCTION}

Digital technology has become an integral part of public schooling across countries since the 1980s (Selwyn 2018), driven by the combination of technological innovation and political determination for efficient governance. Russia is no exception and the recently intensifying introduction of Information and Communication Technology (ICT) into different aspects of education manifests Russia's convergence with the rest of the world. Digitalization increasingly draws the attention of the government, non-state sector and philanthropic organizations (for more, see Chap. 3). They view technology as a solution to a wide range of problems including the lacking and often uneven resources of educational institutions, low or unequal learning outcomes, outdated and unmotivating pedagogies or lack of a consistent monitoring of student progress. In addition, ICT and related skills are perceived as a defining feature of future professional and societal life as well as a means to ensure efficient governance. As a novel and strengthening focus of education policy and pedagogical practice, as well as an increasing source of private revenue, the introduction and actual use of digital education technologies deserve critical academic scrutiny. Scholars of education policy call for studies on the implications of digitalization for education governance,

\footnotetext{
N. Piattoeva $(\varangle)$

Tampere University, Tampere, Finland

e-mail: nelli.piattoeva@uta.fi

G. Gurova
}

Moscow School of Management SKOLKOVO, Moscow Oblast, Russia 
seeing it in the context of the profound turn in the governance of education to "new modes of government and governing where power is not confined to the state or to the market but is exercised through a plethora of networks, partnerships and policy communities who 'consensually' work with stakeholders to produce more flexible, responsive forms of service delivery" (Wilkins and Olmedo 2018, 5).

We focus particularly on two interrelated changes in education governance that have been widely attributed to the rise and operation of digital education technologies. First is the reconfiguration of old and proliferation of new, particularly non-state actors (e.g. Williamson 2017; Hartong 2018) in performing regulation on behalf of or in collaboration with the national governments. Second, we are interested in how digital education technologies act as connecting devices between actors and how they constitute or reconstitute spaces of governance (e.g. Gulson and Sellar 2019; Hartong 2018).

We distinguish between four forms of education digitalization. First, ICT is a resource for teaching and learning in the format, for instance, of online courses that use digitalized textbooks and other virtual materials. Second, digitalization rises to prominence through the teaching of technology as a subject or an extracurricular activity in its own right or as a cross-curriculum theme. In addition, there is overall a growing emphasis on acquiring ICT-related knowledge and skills as a core learning competence (curriculum in coding or robotics). Third, we categorize datafication defined as the "transformation of different aspects of education (such as test scores, school inspection reports, or clickstream data from an online course) into digital data" (Williamson 2017, 5) as a distinct but entangled manifestation of digitalization. Fourth, digitalization entails resourcing educational institutions with hardware, software and other digital infrastructure, so it changes the material environment of education in unprecedented ways. What brings these four forms of digitalization together is the fact that the actors who make them possible "gain increasing control over the field of judgment in education" (Takayama and Lingard 2018, 2 ). Thus, scholars claim that the governance of education is displaced towards new digitalized sites of expertise (Williamson 2017): "while ICT have become translated into the field of education, they simultaneously act as a core medium through which new actors have become authorized as key players to shape output- and accountability-based policy and practice" (Hartong 2018, 135).

Lewis et al. (2016) have urged researchers to acknowledge the complexity of emerging power relations and governance structures and to examine them beyond topographical imaginaries. This is particularly so due to the proliferation of data collection and use enabled by digital technologies that have turned metrics, calculations and comparisons into new means of governance in education enabling new visibilities and proximities. We deploy Harvey's $(2012,77)$ useful distinction between the topological and the topographical in the ensuing analysis: "[i]n topographical mapping, the boundaries of state power appear as commensurate with a clearly defined territorial boundary, and such categorical mappings are echoed in the spatially nested structures of administrative 
division." Topologization, by contrast, draws attention to multiple new spatial figures where borders "do not coincide with the edges of a demarcated territory, and where it is the mutable quality of relations that determines distance and proximity, rather than a singular and absolute measure" (Harvey 2012, 77-78). Datafication produces novel connections between the governing and the governed actors and thus "create(s) and sustain(s) dynamic political and moral spaces" (Harvey 2012, 88). In other words, new possibilities for action and the exercise of power (Lewis et al. 2016) are facilitated by the fact that "presence and proximity (are) no longer simply a question of physical distance" (Allen 2011, 295; Gulson and Sellar 2019).

Situated in relation to an international body of literature and the two arguments pertaining to the contribution of digitalization to the (changing) governance of education, we proceed as follows: we first map the general education policy context within which the earlier and current digitalization efforts have unfolded. The next two sections present analyses of the ongoing policies and practices of education digitalization. First, we show how digitalization changes the character of traditional actors and enables new actors and actor assemblages to enter the scene of education governance and provision. Second, we look specifically at datafication as extending spaces of governance in both a topographical and a topological manner. Topographically, some practices of datafication follow established administrative structures and enable tighter vertical control over regions and education institutions by the federal authorities. But datafication also generates spaces that overcome topographical distance through relationality and connectedness. These manifest, first, in the possibilities of "intimate" governance (see Gorur 2018) reaching into individual subjectivities and, second, intensifying proximities to the global level of education governance bypassing the national authority. Needless to say, we are only able to scratch the surface of the ongoing developments, partly due to the scarcity of existing research and partly because we are dealing with a rapidly moving target. The analysis builds on diverse sources, including our own and others' studies on the digitalization and datafication of Russian education, as well as recent policy documents, media reports and websites of central actors.

\subsection{Policy Context}

Information technologies first entered the Soviet schools as a focus of teaching. Already in 1959, some schools in Moscow and Novosibirsk, the cities best resourced with computers, started teaching the basics of programming and computational mathematics in the name of international competition and efficiency of national economic planning. Political and economic prerogatives, coupled with increased accessibility of computers, transferred education in technology from a subject taught in specialized and elite schools into a compulsory curriculum area. Soviet schools started to teach the course "Principles of Information Science and Technology" in 1985, and in 1990/1991, it was declared a compulsory subject for grades 10 and 11 throughout the Soviet 
Union. The course and the overall introduction of computer technology to schools raised enormous interest among educators, and the proposed new curriculum included topics related to both the technical and mathematical sides of computing, as well as discussion on the role of computers in society more widely. The "computerization" of education was viewed as a necessary step to keep up with progress and to start a pedagogical change away from the "chalk and talk" teaching method (Muckle 1988). The compulsory ICT course retained its socio-political and economic relevance: "Progress in modern electronics, computer technology, and robot technology is not only a critical constituent of the scientific and technological revolution, but also an area in which two societal and economic systems come into direct confrontation" (Vinokurov and Zuev 1985 as cited in Monakhov 1986, 143). In other words, teaching in and with technology was a means of making a contribution to the Cold War arms and space race between the Union of Soviet Socialist Republics (USSR) and the "capitalist West." It is also important to mention the anticipated impact of technology on students' worldviews. The newly introduced school subject had to foster a "communist upbringing" and to enhance students' understanding of the world through objective mathematical models (Monakhov 1986, 148). Prerequisites for international collaboration existed long before the USSR "opened up" to the West, as Soviet pedagogues and programmers continuously studied, for example, US-developed programmed instruction and other international experiments in computer-based learning (Davydov and Rubtsov 1991; Afinogenov 2013; Tatarchenko 2019). Moreover, despite the fact that the late-Soviet developments in education technology were shortlived due to the collapse of the Soviet regime, these experiences continue to shape current expertise in and imaginaries of digital technology and its role in society (Tatarchenko 2019).

In 1992 the new Law on Education permitted education institutions more freedom in choosing curriculum and pedagogy, and in making financial and operational decisions. They were also allowed and even encouraged to seek private sources of funding. At the same time, a severe economic crisis caused abrupt cuts in state subsidies and pushed schools and universities to raise money through tuition fees, tutoring services and even by renting out premises. Many administrative and fiscal responsibilities were transferred from central to regional and local authorities in order to enable regionally and locally tailored solutions and in some cases survival strategies. In practice, decentralization led to increasing inequalities between regions and within them-between rural and urban areas-and made the education sector less transparent to the federal center (Polyzoi and Dneprov 2010).

In the 2000s the Russian Ministry of Education and Science issued several strategic and legislative documents that stressed the role of education in ensuring national economic growth, global competitiveness and human capital development, promoted the introduction of market mechanisms into the education sector, and called for the efficiency, transparency and accountability of education institutions (Gounko and Smale 2007). Tackling economic 
deficiencies in education, the government used loans from the World Bank for particular education reforms, including those enhancing "efficient use of digital learning resources and electronic tools" (World Bank 2004), to complement federal funding for education. The government then introduced measures of centralized control, such as state standards, accreditation, licensing and centralized examinations, and a scheme of funding tied to the attainment of nationally determined indicators and outcomes. Reforms were designed to increase governmental and organizational efficiency, stimulate cost optimization, reduce space for lobbying and corruption in public funds allocation and ensure the overall realization of state priorities through outcome monitoring (Yastrebova 2013; OECD 1999). Further prerequisites for the digitalization and datafication of Russian education were thus created on the one hand by the opening up and commercialization of the education sector that started in the early 1990s, and on the other hand by the state's embracement of the New Public Management (NPM) paradigm since the 2000s.

A significant latest leap in digitalization policies was prompted by the reelection of Vladimir Putin and the publication of his "decrees" of May 2018. These include the task of "ensuring an accelerated implementation of digital technologies in the economic and social spheres" (Prezident 2018; see also Kolesnikova 2018). ${ }^{1}$ Specifically for education, the task is to create a "modern and safe digital education environment which ensures high quality and access to education at all levels" (ibid.). The decree continues and expands the "Digital educational environment" project (neorusedu.ru) launched in 2016, but takes digital education to the next level. The aim of education modernization for 2018-2024 is to ensure international competitiveness of Russian education and Russia acquiring a position among top-10 leading countries with the best quality of education according to international education rankings (Government of Russia 2018). "Development of digital education environment" is outlined as one of ten priority sub-projects, while the other nine subprojects also feature different aspects of digitalization (ibid.). What is worth highlighting is the aim to establish a federal center for digital education transformation, to create a centralized federal platform that would compile information on and services in education, the related call to increase the provision of online courses and digitalize education administration and federal support for an increasing number of in-school and extra-curricular activities related to teaching ICT.

\subsection{The Rise of New Actors and Actor Assemblages}

In this section we document some examples of the entry of for-profit actors and philanthropies into the field of education by means of education digitalization. Their contribution is vital for the federal government to realize its political prerogatives of digitalization. At the same time, for-profit organizations are becoming increasingly attracted to the education sphere due to the prospect of new revenues and the opportunity to reach out to young people as future 
employees and consumers. Growing proximity to the decision-makers through new actor assemblages enables these actors to communicate their visions of the future, and their political and economic interests, to legislative and executive bodies. Both more traditional education actors, such as textbook publishers and new actors, such as Internet service providers, the banking sector and industry, promote digitalization. Co-operation with multinational technology providers and international intergovernmental organizations manifests the growing entanglement between national and international actors.

Publishing houses promote digital learning materials and develop online platforms for teachers and students. A major education publisher Prosvêsenie (Enlightenment, https://prosv.ru/)—exclusive supplier of standardized education literature in the Soviet Union-has lately regained its central position and holds a 40 per cent share of the country's educational market (Prosveŝenie 2017). Some commentators claim that it has (re)monopolized the textbook market (ibid.) and that its substantial revenues come solely from state contracts (Bryzgalova 2017; Becker and Myers 2014). By now Prosvêsenie has digitalized the entire spectrum of its textbooks, though questions are raised about the actual availability of ICT infrastructure in schools and the danger of growing inequalities among schools and students as to their access to digitalized education products. Prosvêsenie contracted Microsoft to enable access to digital education on Microsoft tablet personal computers (PC), but the agreement was terminated due to international sanctions on the company's former chair of board Arkady Rotenberg (Microsoft zamorozil 2014). However, the task was taken over by Samsung with the successful sale of tablets starting in the summer of 2017. In 2017, Prosvêsenie also signed a US\$ 1.1 million deal with the Russian Internet service provider Yandex to develop an online platform for schoolchildren, teachers and parents with self-proclaimed elements of machine learning and personalization. Yandex has been actively developing education services and products, including prep materials across compulsory school subject areas (Gerden 2017; Analiz dannyh n.d.; Yandex ǚebnik n.d.).

Several large Russian high-tech companies with mixed ownership (such as AFK Sistema, Rosnano, Sberbank, Bazovyj Element) have launched influential philanthropies that claim to improve school and higher education particularly via access to and provision of education technologies. Bazovyj èlement's (Basic Element) charity Vol'noe Delo (Voluntary Work) runs a large-scale program for schools on new pedagogical methods (http://volnoe-delo.ru/directions/ education/inzhenery-novogo-pokoleniya/), and Rosnano (Russian Corporation of Nanotechnologies) offers schools and higher education institutions an online platform with distance education courses in science, technology, engineering and mathematics (STEM) subjects, calling it "a large-scale online project that forms the professions of the XXI century." The project includes support and recommendations to teachers (https://edunano.ru/ stemford/).

For-profit players, government actors, academic institutions and intergovernmental organizations form novel assemblages that increase their influence 
and opportunities for action in the arena of education digitalization. An example of such an assemblage can be found in the flagship project Competencies of the 21st Century of Sberbank's (a state-owned Russian banking and financial services company headquartered in Moscow) philanthropy Vklad $v$ budisiee (Investment in the Future, https://vbudushee.ru/). The project sponsored the preparation of a research report that makes "recommendations for the transformation of Russian school that would enable to close the gap between the education system and the demands of real life." The report was prepared in 2018 by a major Russian think tank in education policy, the Institute of Education at the Higher School of Economics, in co-operation with the Organization for Economic Co-operation and Development (OECD) Education 2030 group and the United Nations Educational, Scientific and Cultural Organization (UNESCO) experts (Kompetencii 21 veka n.d.). The report has been widely cited in the Russian media and presented on various public and government forums. The number one "new literacy" advocated in the report is digital literacy (Kompetencii i gramotnost' n.d.). Simultaneously, Sberbank's CEO announced that the corporation is developing a digital learning platform to be ready for use in 2019. The platform will be open to schools free-of-charge, and will enable personalized learning, pupil's choice of pedagogy, study outside of school, and continuous monitoring of educational achievement (Sberbank rabotaet 2018).

Other active players include EdTech startups, small and medium-sized education businesses, startup accelerators (e.g. Skolkovo Innovation Center or Russian Venture Company, RVC, https://www.rvc.ru/en/), and business forums that promote the EdTech agenda, such as the yearly EdCrunch exhibition (https://2019.edcrunch.ru/). In 2018 the head of RVC announced the creation of a new investment fund that will focus solely on education technologies (Futur'e 2018); and a government representative commented at the Open Innovations Forum in autumn 2018 that the government will stimulate EdTech initiatives and assist their access to schools, universities and state-owned companies in order to facilitate their development, since Russia has good potential for becoming a global-level player on the EdTech market.

\subsection{Datafication Extending Spaces of Governance}

Education digitalization manifests particularly as a process of encoding ever more complex educational processes into software products (Williamson 2017), which has led to and is entangled with another major development, namely education datafication. Digitally produced or analyzed and visualized data can be inserted into databases, allowing different actors and their performances to be measured, evaluated and re-presented, and decisions to be made on the basis of data and their analysis. Education administration at different levels of governance and across educational institutions is increasingly datadriven, underpinned by the need to both produce and use indicators, data analytics and other forms of "objective evidence." This is the development to 
which we next turn. We perceive datafication as both entangled with and distinct from digitalization. Datafication manifests as a process of data collection and deployment in its own right, for instance, through the exercise of quality evaluation and testing of learning outcomes and intensifies through the deployment of digital technologies, such as students' engagement with electronic teaching materials and games and teachers' reporting in electronic journals. Datafication is likely to intensify in the coming years, opening the door further to new actors and actor assemblages (as discussed in the previous section) and extending governance practices topologically, that is, cutting across established spatialities and composing new proximities and continuities, and thus spaces of governance, by means of datafication (Allen 2011).

In the environment of both the intended and the unintended diversification of education (see Sect. 10.2), the federal government has realized the potential of controlling education by means of data. The proclaimed demand for output data reproduces arguments about the need to increase efficiency and accountability of federal and sub-national executive authorities, to close the policy implementation gap and to fight against corruption and thus to pave the way for meritocracy and equality of opportunity (Piattoeva 2018). The development of centralized examinations and national surveys of education quality were strongly recommended by international actors such as the OECD and the World Bank. Russia participated in international large-scale assessments of learning outcomes to compare its educational achievements to international standards and to students' performance in other (Western) countries (PISA, TIMMS, PEARLS; PIAAC; TALIS). ${ }^{2}$ On a smaller scale, managerial and market approaches prompted educational institutions to become more customeroriented, to collect regular feedback from students and parents and to test students to monitor their progress "objectively." All these activities involve the gathering and analysis of data of rising quantity and breadth with the help of computers and software (for more on government data outside education, see Chap. 22).

The key driver and the first manifestation of the datafication of education, the Unified State Exam (USE), was introduced on an experimental basis in 2001 and was launched nation-wide in 2009. The examination combined the functions of the school graduation test and the national university entrance test, then gradually became a central source of information on educational achievement. The USE now serves as a means of external quality control of schools and universities, promotes national education standards and closer proximity between the official curriculum and actual classroom practices (Piattoeva 2015). Since 2009, USE as a measure of quality and a source of data about schools has been supplemented with the annual VPR (Vserossijskie proverocnye raboty, All-Russia Examinations) and a sample-based NIKO (Vserossijskie Nacional'nye issledovaniâ kăcestva obrazovaniâ, National Study of Education Quality). These studies multiply federally driven education datafication and show how the federal center intensifies new topographically bordered proximities between the federal authorities and the regions through data, 
rendering different actors not only amenable to control by making them more transparent, but also by attaching sanctions and rewards to quantitative outcomes, thus guiding the actors "softly" towards particular political ends (Piattoeva 2015; Hartong and Piattoeva 2019). In this manner, the government makes its presence felt at a distance, enabling "powers of reach" and "powers of connection" to create specific political spaces (Allen 2011).

The emergence of government-sponsored datafication has given rise to state-level organizations responsible for data-driven education quality control, such as Rosobrnadzor (Federal Service for Supervision in Education and Science), that gradually gained such powers that it rivaled the Ministry of Education and Science in the decisions about closing down education institutions deemed inefficient in terms of assessment results. In this sense, internal state structures, too, are being adjusted - and empowered or disempoweredby data-driven education governance. Simultaneously, experts in education measurement, psychometrics and software are gaining in power: for example, a small private association, the Moscow Center for Continuous Mathematical Education (www.mccme.ru) has gained the status of a prominent expert after developing NIKO (see above) and publicizing the ranking tables of Russian schools on a contractual basis with the federal government. Simultaneously, as regions, schools and even individual teachers are increasingly controlled through the practices of data production, small-scale paid-for services emerge to offer, for example, commercial diagnostics of student achievement, paid-for student academic contests and a variety of local ranking exercises providing documentary proof of "high performance." In this manner, governmentsponsored datafication initiatives, carrying high stakes, feed the emergence of supplementary datafication services to help students, teachers and schools to manage the pressure, amplifying data collection exercises and the volumes of data produced (see Gurova et al. 2018).

While intensifying data collection through national tests intends to make educational affairs in regions and schools transparent and thus legible to federal-level governance and its attempts to standardize and unify, other developments speak of simultaneous differentiation in the system. In 2016, the city of Moscow initiated its participation in the "PISA for schools" international large-scale assessment (Lučšie iz lučših 2016). Following the prototype of the OECD's Programme for International Student Achievement (PISA), PISA for schools enables school-to-school comparisons (Lewis et al. 2016). This benchmarked Moscow against schools in top-ranked countries and metropolises and enabled the Moscow authorities to proclaim that "Moscow school education is among the six best systems in the world, in terms of reading and mathematical literacy and among the top 20 in terms of scientific literacy." The study not only highlighted that the quality of education in Moscow is much higher than in Russia on average, but also, and importantly for this paper, showed how local authorities can initiate alternative or complementary data collection exercises for their own political and administrative aims (Six facts 2017). Through PISA for schools, the Moscow administration bypassed topographically defined 
administrative borders and initiated topological relations with one of the key actors in global education governance and established proximity between its (successful) system of education and world "best performers," while distancing itself from the rest of the country. Moscow's success in PISA for schools was partly attributed to its advances in education digitalization, and a recent initiative promotes partnering between Moscow schools and schools around Russia to disseminate Moscow's experience on a school-to-school basis, setting up Moscow as an example to emulate. The "Moscow electronic school" project has been marketed as an outstanding innovation even capable of arousing international interest in Russian education among world education leaders (https://www.mos.ru/en/news/item/48603073/; https://hundred.org/ en/innovations/moscow-electronic-school). In this example, we see how commensurative practices enable topological relations that produce new continuities between disparate education systems by locating them on a common metric-Moscow alongside international high-performing systems and cities, but also connecting schools across regions, bypassing the usual regional and municipal levels of education governance. But these new continuities also condition the production of discontinuities within the national space of governance- that is, marking out Moscow as a system in its own right and distinct from the rest of the country due to documented international success. These new dis/continuities facilitated by data create new spaces of and opportunities for educational governance-possibly contradicting the federal officials' efforts to create a unified national education space.

Finally, in an attempt to envisage the future, we want to highlight the intensifying interrelationship between digitalization and datafication, enabling their mutual enhancement and complex governance arrangements that will increasingly work on and pervade individual subjectivities. The government-initiated organization Agency for Strategic Initiatives, ASI (Four Years of Agency for Strategic Initiatives 2017) plays the role of the government's champion of the digitalization of all economic and social spheres and aspires to be the moderator for other private and public actors. It enjoys significant financial resources and symbolic support from Vladimir Putin and the Presidential Administration, and makes recommendations in the format of roadmaps to major actors such as federal and regional ministries and professional associations. ASI runs the project of the University for the National Technological Initiative (https://asi. $\mathrm{ru} /$ news/85128/) in which digital platforms and tools mediate all educational activities from the school level to adult education (Koncepcia universiteta n.d.). In 2018 ASI showcased digital education in a pilot education event for over one thousand participants. To gain admission, participants had to participate in several online tests, questionnaires and computer games, which assessed their performance and personal qualities by means of artificial intelligence (AI). AI simultaneously used these data for training the algorithm. The successful participants received personal online profiles, appraisal of their individual potential and recommendations for further learning in one of the six professional directions - presumably those which, in ASI's estimation, would be most relevant in 
the future: data analyst, technologist, entrepreneur, organizer, community leader and ecosystem architect. During the event, every participant's activities were continuously assessed and digitally documented. Their biometric data such as stress levels were also stored. On the basis of these data, participants were awarded points which they could use to gain access to education activities; they were also grouped according to their profiles and given recommendations for individual educational trajectories. The system analyzed which contacts would be most useful for each participant and connected participants with each other. After the event the organizers boasted about the vast amount of data collected (through audio and video records, participants' logs into the digital platform, bracelets that tracked biometric data, and so on). The data are to be used in the assessment of all participants' competencies and literacies and to make recommendations for their future jobs and education, as well as for the further development of artificial intelligence to guide future educational activities. The aim is that digital tools would enable direct co-ordination of personalized learning activities rather than continue to organize educational institutions that "teach everyone the same way" in an outdated "industrial époque" fashion. The tools and approaches piloted by ASI are expected to provide guidance for the development of other educational institutions, primarily universities, but also schools, professional colleges and extracurricular education organizations.

\subsection{Conclusion}

This chapter has documented the ongoing expansion of education digitalization and datafication that affects how Russian education is governed-who the important actors are in setting and implementing education priorities and how these priorities are put into practice. Digitalization creates space for an array of new actors to have a say in Russian education, though it must also be noted that the prerequisites for their involvement have been established by the federal state throughout the post-Soviet period and even earlier. Digitalization has led to an increased role of the philanthropic, business and voluntary sectors of society in the processes of education policy-making and delivery, while simultaneously changing the nature of and instruments available for more traditional players such as textbook publishers or executive-level authorities.

Whereas on the one hand, digital technologies help to re-center national authorities in the governance of education, the processes of digitalization, enjoying considerable support from current national policies across sectors and public discourse, do not entirely emanate from and are therefore are not entirely controlled by the national authorities. The examples documented here show how they also unfold as a loose and spontaneous grassroots process, as a development promoted and steered by multiple public, private, mixed, individual and collective actors and their respective interests. Therefore, we propose that further digitalization of Russian education is likely to produce two co-existing realities: one in which certain aspects of education are 
re-centralized by means of digital technology and in turn re-center the state in the activity of education governance, and the other, in which the proliferation of digital technologies leads to further diversification, raptures and inconsistencies in the education system. Both, however, manifest and generate novel governance relations between actors that elude description in a solely traditional topographical manner. As actors create complex arrangements between old and new state, private for-profit, academic and international intergovernmental organizations, they make the sphere of education governance in Russia more complex.

If the plans of the government materialize, Russian education system will soon produce increasing amounts of data far beyond what has been deliberately generated through systems of examinations and national assessments of education quality and learning outcomes. This also means that the governance of education will shift from human actors using data to govern to the governed actors engaging with the data that govern-what Williamson (2017) has called "digital education governance." More data production will be possible by means of students' continuous engagement with the digital environment through online learning resources and databases, as well as the more regulated and regular participation of schools and other educational institutions in quality monitoring exercises. The production, analysis and utilization of (numerical) data within the new regimes of education governance present a whole range of mechanisms that enable governance at a distance. In addition, new kinds of connectivities will emerge and effectively change the co-ordinates of governance as data increasingly reach individuals and groups that may have been beyond (topographical) reach (see Lewis et al. 2016). Local authorities and schools are now in a situation where they are rendered quantifiable and visible through intimate data (Gorur 2018). Transparency potentially renders them legible and amenable to control and intervention at any time. Moreover, by means of producing and publicizing data on themselves, institutions are guided towards aligning their work with a particular set of expectations (Piattoeva 2015). The plans to create individual digital portfolios for every teacher and student reflect a desire to reach these individuals by uploading their data and tracking their activities at every step of their educational lives. Penetrating the motivation structures and choices of teachers and students (e.g. by tracking and AI-analyzing their activities in the digital educational environment; by gamifying education and assigning scores and bonuses for certain activities) seek a similar intimate effect on subjectivity.

\section{Notes}

1. All translation from Russian are ours unless stated otherwise.

2. These abbreviations stand for the following international large-scale assessments: OECD's Programme for International Student Assessment (PISA), OECD's PIAAC (Programme for the International Assessment of Adult Competencies); IEA's (International Association for the Evaluation of Educational Achievement) 
TALIS (Teaching and Learning International Survey;) IEA's Trends in International Mathematics and Science Study (TIMMS), and IEA's Progress in International Reading Literacy Study (PIRLS).

\section{REFERENCES}

Afinogenov, Gregory. 2013. Andrei Ershov and the Soviet Information Age. Kritika: Explorations in Russian and Eurasian History 14 (3): 561-584.

Allen, John. 2011. Topological Twists: Power's Shifting Geographies. Dialogues in Human Geography l (3): 283-298.

Analiz dannyh. n.d. [Data Analysis]. https://academy.yandex.ru/events/data_analysis/. Accessed 8 Jan 2019.

Becker, Jo, and Steven Lee Myers. 2014. Putin's Friend Profits in Purge of Schoolbooks. The New York Times. https://www.nytimes.com/2014/11/02/world/europe/ putins-friend-profits-in-purge-of-schoolbooks.html. Accessed 14 Jan 2019.

Bryzgalova, Ekaterina. 2017. Samsung vypustil obrazovatel'nyj planšet na baze učebnikov Prosvêseniâ [Samsung Launched an Educational Tablet on the Basis of Prosvêsenie's Textbooks]. Vedomosti. https://www.vedomosti.ru/technology/ articles/2017/08/29/731444-samsung-obrazovatelnii-planshet. Accessed 14 Jan 2019.

Davydov, V., and V. Rubtsov. 1991. Trends in the Informatization of Soviet Education. Soviet Education 33 (2): 58-70.

Four Years of Agency for Strategic Initiatives’ Work Were "Not in Vain” - Putin. 2017. https://asi.ru/eng/news/detail.php?ELEMENT_ID=84440. Accessed 15 Dec 2018.

Futur'e, Èduard. 2018. RVK zajmetsâ vnedreniem virtual'noj real'nosti [RVC Will Work on the Implementation of Virtual Reality]. https://www.ridus.ru/ news/272584. Accessed 15 Dec 2018.

Gerden, Eugene. 2017. Edtech: Russian Publisher Prosveshbenie Announces a Digital Educational Platform. Publishing Perspectives. https://publishingperspectives. com/2017/06/prosveshcheniye-yandex-digital-education-partnership-russia/. Accessed 14 Dec 2018.

Gorur, Radhika. 2018. Escaping Numbers? Intimate Accounting and the Challenge to Numbers in Australia's 'Education Revolution'. Science \& Technology Studies 31 (4): 89-108.

Gounko, Tatiana, and William Smale. 2007. Modernization of Russian Higher Education: Exploring Paths of Influence. Compare 37 (4): 533-548.

Government of Russia. 2018. Pasport nacional'nogo proekta 'Obrazovanie' [Passport of the National Project 'Education']. http://mo.mosreg.ru/download/document/1524233. Accessed 24 Nov 2018.

Gulson, Kalervo, and Sam Sellar. 2019. Emerging Data Infrastructures and the New Topologies of Education Policy. Environment and Planning D: Society and Space 37 (2): 350-366.

Gurova, Galina, Helena Candido, and Xingguo Zhou. 2018. Effects of Quality Assurance and Evaluation on Schools' Room for Action. In Politics of Quality in Education: A Comparative Study of Brazil, China, and Russia, ed. Jaakko Kauko, Risto Rinne, and Tuomas Takala, 137-160. London: Routledge.

Hartong, Sigrid. 2018. Towards a Topological Re-Assemblage of Education Policy? Observing the Implementation of Performance Data Infrastructures and 'Centers of Calculation' in Germany. Globalisation, Societies and Education 16 (1): 134-150. 
Hartong, Sigrid, and Nelli Piattoeva. 2019. Contextualizing the Datafication of Schooling - A Comparative Discussion of Germany and Russia. Critical Studies in Education (online first).

Harvey, Penelope. 2012. The Topological Quality of Infrastructural Relation: An Ethnographic Approach. Theory, Culture \& Society 29 (4-5): 76-92.

Kolesnikova, Ksenija. 2018. "Klass BigData. Kak bol'šie dannye i 'cifra' izmenât rossijskie školy [The Class of Big Data. How Big Data and the Digital Will Change Russian Schools].” Rossijskaâ gazeta 7717 (254). https://rg.ru/2018/11/12/ kak-bolshie-dannye-i-cifra-izmeniat-rossijskie-shkoly.html. Accessed 8 Jan 2019.

Kompetencii 21 veka [Competencies of 21 st Century]. n.d.. https://vbudushee.ru/. Accessed 15 Dec 2018.

Kompetencii i gramotnost' n.d. = Kompetencii i gramotnost': operacional'naâ ramka [Key Competencies and Literacy: Conceptual Frame]. n.d.. https://ioe.hse. $\mathrm{ru} / 21$ skills/ks/list. Accessed 15 Dec 2018.

Koncepciâ universiteta n.d. = Koncepciâ universiteta nacional'noj tehnologičeskoj iniciativy 2035 [Concept of the University of the National Technology Initiative 2035]. n.d.. https://2035.university/upload/iblock/0a9/0a9231d2eecaf8e5165a2cf38a 5e488f.pdf. Accessed 8 Jan 2019.

Lewis, Steven, Sellar Sam, and Bob Lingard. 2016. PISA for Schools: Topological Rationality and New Spaces of the OECD's Global Educational Governance. Comparative Education Review 60 (1): 27-57.

Lučšie iz lučših 2016 = Lučšie iz lučših: čego dobilis' moskovskie školy [Best of the Best: What Moscow Schools Have Achieved]. 2016. https://www.mos.ru/news/ item/17830073/. Accessed 20 Dec 2018.

Microsoft zamorozil 2014 = Microsoft zamorozil programmu po sozdaniû planšeta dlâ rossijskih škol'nikov [Microsoft Stopped the Programme for Developing a Tablet for Russian Schoolchildren]. 2014. https://www.interfax.ru/russia/405195. Accessed 13 Jan 2019.

Monakhov, V.M. 1986. The Content of the Basic Information Science and Computer Technology Course. Soviet Education 28 (10-11): 142-155.

Muckle, James. 1988. A Guide to the Soviet Curriculum: What the Russian Child Is Taught in School. Beckenham: Croom Helm.

OECD. 1999. Country Background Report for the Russian Federation. Reviews of National Policies for Education. Paris: OECD Publications.

Piattoeva, Nelli. 2015. Elastic Numbers: National Examinations Data as a Technology of Government. Journal of Education Policy 30 (3): 316-334.

- 2018. Doing Equality Through Greater Transparency? Troubling Surveillance Expansion in the Russian School System. In Equity in and Through Education: Changing Contexts, Consequences, and Contestations, ed. Stephen Carney and Michele Schweisfurth, 157-173. Rotterdam: Sense Publishers.

Polyzoi, Eleoussa, and Eduard Dneprov. 2010. A Framework for Understanding Dramatic Change: Educational Transformation in Post-Soviet Russia. In PostSocialism Is Not Dead:(Re) Reading the Global in Comparative Education, ed. Iveta Silova, 155-179. Emerald Group Publishing Limited.

Prezident 2018 = Prezident podpisal Ukaz "O nacional'nyh celâh i strategičeskih zadačah razvitiâ Rossijskoj Federacii na period do 2024 goda" [President Signed Decree "On the National Goals and Strategic Development Tasks of the Russian Federation for the Period Until Year 2024"]. 2018. http://kremlin.ru/events/ president/news/57425. Accessed 24 Nov 2018. 
Prosveŝenie. 2017. https://prosv.ru/eng.

Sberbank rabotaet 2018 = Sberbank rabotaet nad sozdaniem obrazovatel'noj platformy dlâ škol [Sberbank Works on the Development of Educational Online Platform for Schools]. 2018. https://tass.ru/obschestvo/5274119. Accessed 4 Oct 2019.

Selwyn, Neil. 2018. Technology as a Focus of Education Policy. In The Wiley Handbook of Education Policy, ed. Rosemary Papa and Shadow W.J. Armfield, 459-477. Chichester: John Wiley \& Sons.

Six Facts About Moscow Schools: City Education in 2016. 2017. https://www.mos. $\mathrm{ru} / \mathrm{en} / \mathrm{news} /$ item/19625073/. Accessed 8 Jan 2019.

Takayama, Keita, and Bob Lingard. 2018. Datafication of Schooling in Japan: An Epistemic Critique Through the 'Problem of Japanese Education'. Journal of Education Policy 34 (4): 449-469.

Tatarchenko, Ksenia. 2019. Thinking Algorithmically: From Cold War Computer Science to the Socialist Information Culture. Historical Studies in the Natural Sciences 49 (2): 194-225.

Wilkins, Andrew, and Antonio Olmedo. 2018. Introduction: Conceptualizing Education Governance: Framings, Perspectives and Theories. In Education Governance and Social Theory, ed. Andrew Wilkins and Antonio Olmedo, 1-17. London: Bloomsbury.

Williamson, Ben. 2017. Big Data in Education: The Digital Future of Learning, Policy and Practice. London: Sage.

World Bank. 2004. Project Appraisal Document on a Proposed Loan in the Amount of US\$ 100 million to the Russian Federation for an E-learning Support Project in Support of the First Phase of the Government's Education Modernization Program. Washington, DC: World Bank http://documents.worldbank.org/curated/ en/603841468760158792/text276500RU.txt.

Yandex učebnik [Yandex Textbook]. n.d.. https://education.yandex.ru/. Accessed 8 Jan 2019.

Yastrebova, O.K. 2013. O principah formirovaniâ normativov poduševogo finansirovaniâ obrazovatel'nyh programm vysšego obrazovaniâ [On the Principles of Forming Per Capita Normatives of Funding of Educational Programmes of Higher Education]. Informacionno-metodičeskij seminar 'Realizaciâ obrazovatel'nyh programm vysšego obrazovaniâ' [Information and Methods Seminar on 'The Implementation of Higher Education Programmes']. https://docplayer. ru/30287522-O-k-yastrebova-konsultant-minobrnauki-rossii.html. Accessed 28 Dec 2018. 
Open Access This chapter is licensed under the terms of the Creative Commons Attribution 4.0 International License (http://creativecommons.org/licenses/ by/4.0/), which permits use, sharing, adaptation, distribution and reproduction in any medium or format, as long as you give appropriate credit to the original author(s) and the source, provide a link to the Creative Commons licence and indicate if changes were made.

The images or other third party material in this chapter are included in the chapter's Creative Commons licence, unless indicated otherwise in a credit line to the material. If material is not included in the chapter's Creative Commons licence and your intended use is not permitted by statutory regulation or exceeds the permitted use, you will need to obtain permission directly from the copyright holder. 